\title{
PROTECTION AND PRESERVATION SEA ENVIRONMENT IN INTERNATIONAL LAW PERSPECTIVE
}

\author{
Agoes Djatmiko \\ Fakultas Hukum Universitas Wijayakusuma Purwokerto \\ Email : agoesdj.2017@gmail.com \\ Elisabeth Pudyastiwi \\ Fakultas Hukum Universitas Wijayakusuma Purwokerto \\ Email : epudyastiwi@gmail.com
}

\begin{abstract}
Protection of the marine environment within the framework of international law is actually an accumulation of The Principle of National Sovereignity and The Freedom of High Sea. The International Maritime Organization (IMO) states that "a right on the part of an astat threatened with the environmental injury from sources beyond its territorial jurisdiction, at least where those sources are located on the high seas, to take reasonable action to prevent or abate that injury ". The general principle of good neighbor liness can be found in international customary law as well as in Article 74 of the UN Charter. This principle is reflected in several international treaties and is supported by the country's main practices in dangerous and emergency activities. Cooperation is contained in the 24th Principle of the Stockholm Declaration and the 27th Principle of the Rio Declaration which states that countries must cooperate in the principles of good faith and the spirit of partnership as efforts to protect the environment.
\end{abstract}

Keywords: protection of the marine environment, principles of good faith, International Maritime Organization (IMO)

\section{Introduction}

A sustainable environment is a gift from God Almighty that must be maintained and developed in order to remain a source of life support for humans and other living things for the sake of survival and improvement of the quality of life itself (Umar, 2011: 21). Environmental damage caused by two factors, including environmental damage by nature and by humans. Environmental damage caused by nature such as volcanic eruptions, earthquakes, hurricanes, and so on. Environmental damage caused by humans, for example, such as illegal logging, illegal disposal of plastic waste, poaching, and others.

Environmental damage is a dangerous threat to human survival, so fast and serious attention and treatment must be done immediately. Environmental pollution often occurs not only in the environment on land, but environmental pollution often also occurs at sea. The sea is part of the 
environment that has benefits and a very large role for human life. In history, the sea has proven to have various functions, including as a source of food, trade highways, transportation facilities, recreational / tourist attractions, and a means of unifying or unifying the nation (Masdin, 2016: 1-2). Pollution of the marine environment can cause damage to the preservation of the environment and natural resources in the sea to be disturbed (Mangku, D. G. S. (2010).

The pollution in question is a change in unfavorable sea conditions (detrimental, damaging), caused by the presence of foreign objects due to human actions or natural processes such as industrial remains, municipal waste, petroleum, biocides, hot water from cooling, and so on (Syofyan, 2010: 143). Article 1 number 2 Government Regulation Number 19 of 1999 concerning Control of Marine Pollution and / or Destruction states that the definition of marine pollution is the entry or inclusion of living creatures, substances, energy, and / or other components into the marine environment by human activities so that the quality decreases until to a certain degree that causes the marine environment to no longer conform to its quality standards and / or functions. Pollution of the marine environment can be interpreted that the presence of dirt or waste products of living things that enter the sea area directly or indirectly (Mangku, D. G. S;2011). Sources of pollution of the marine environment include oil spills, emissions of sea transportation, remnants of war ammunition, oil drilling at sea, disposal of industrial waste to the sea, garbage disposal from land transportation through river flow and disposal of objects containing chemicals from the waters.

Pollution of the marine environment caused by oil spills has become a concern of the wider community whose consequences are very quickly felt by people around the coast, significantly damaging living things around the coast and can even spread far into the sea areas of other countries (Rehulina and Hermanto, 2015: 70-71). The development of marine pollution problems in the world is increasing rapidly as there is a lot of activities at sea, such as exploration and exploitation of natural resources, offshore drilling, sea transportation and so on. Activities or activities at sea have an impact on the occurrence of marine pollution such as oil spills and spills of hazardous substances or objects into the sea. Attention to marine pollution has implications for ecosystems and ecology including marine resources in the field of fisheries as well as influences on coastal life. Pollution is usually caused by ships, offshore drilling, and disposal of hazardous substances into the sea. Of course this has a negative impact on the marine environment and coastal communities so that it requires comprehensive dispute resolution (Syofyan, 2010: 140141). Pollution of the marine environment can cause damage to the preservation of the environment and 
natural resources in the sea to be disturbed. The pollution in question is a change in unfavorable sea conditions (detrimental, damaging), caused by the presence of foreign objects due to human actions or natural processes such as industrial remains, municipal waste, petroleum, biocides, hot water from cooling, and so on (Syofyan, 2010: 143).

Article 1 number 2 Government Regulation Number 19 of 1999 concerning Control of Marine Pollution and / or Destruction states that the definition of marine pollution is the entry or inclusion of living creatures, substances, energy, and / or other components into the marine environment by human activities so that the quality decreases until to a certain degree that causes the marine environment to no longer conform to its quality standards and / or functions. Pollution of the marine environment can be interpreted that the presence of dirt or waste products of living things that enter the sea area directly or indirectly (Mangku, D. G. S. (2012). Sources of pollution of the marine environment include oil spills, marine transportation emissions, remnants of war ammunition, oil drilling processes at sea, disposal of industrial waste to the sea, waste disposal from land transportation through river flows and disposal of objects containing chemicals from the waters. Pollution of the marine environment caused by oil spills has become a concern of the wider community whose consequences are very quickly felt by people around the coast, significantly damaging living things around the coast and can even spread far into the sea areas of other countries (Rehulina and Hermanto, 2015: 70-71). The development of marine pollution problems in the world is increasing rapidly as there are many activities at sea, such as exploration and exploitation of natural resources, offshore drilling, sea transportation and so on. Activities or activities at sea have an impact on the occurrence of marine pollution such as oil spills and spills of hazardous substances or objects into the sea. Attention to marine pollution has implications for ecosystems and ecology including marine resources in the field of fisheries as well as influences on coastal life. Pollution is usually caused by ships, offshore drilling, and disposal of hazardous substances into the sea. Of course this has a negative impact on the marine environment and coastal communities so that it requires comprehensive dispute resolution (Syofyan, 2010: 140141).

Protection of maintenance of the marine environment is increasingly attracting the attention of various parties, both manifested in the form of cooperation between countries in certain regions and research conducted by the country itself. $\mathrm{M}$. Daud Silalahi stated that pollution can be interpreted as a form of environmental impairment, a disturbance, change, or destruction, even the presence of foreign objects in it which causes environmental elements to not function properly 
(Rusmana, 2012). Symptoms of damage to the marine environment that occur at this time can not be separated from human activity itself. The marine environment is closely related to environmental issues in general and the environment at sea in particular with regard to the region (Parthiana, 2014: 226). At this time the pollutant that is dangerous and often pollutes the marine environment is oil. The oil industry in the world is developing very fast, but accidents that result in the scattering of oil in the oceans are almost inevitable, so that, if an oil spill in the oceans will result in pollution of the marine environment. Environmental pollution by oil spills in the ocean will cause oil to float on the surface of the sea which eventually carried by the current and carried to the coast. According to the Maritime and Fisheries Research Center (BRKP), 3 to 4 million tons of oil pollutes the marine environment each year (Chandra, 2015).

\section{Formulation of the problem}

What are the legal arrangements for the protection and preservation of the marine environment according to international law?

\section{Discussion}

Principles for the Protection and Preservation of the Marine Environment

According to Philippe Sands in his book entitled "Principle of International Environmental Law", the definition of environmental law is related to two aspects, firstly related to the scope of the legal subject and its institutional competence; second, related responsibility for environmental damage (Isfarin, 2012: 211). The 1972 Stockholm Declaration (Mangku, D. G. S. (2013), in Principle 2 states that what is called the natural resources on earth are "air, water, land, flora, fauna ... and natural ecosystems". In general, according to Philppe Sands whose opinion was quoted in a journal belonging to Nadia Nurani Isfarin entitled "Protection of the Malacca Strait Sea Environment from Transboundary Oil Pollution", the protection and preservation of the marine environment has several general principles, namely: Sovereignity Over Natural Resources and the Responbility not to Cause Damage to the Environment of other States or to Areas Beyond National Jurisdiction.

As the oldest principle in international law, sovereignty is the main characteristic of a country. According to John O'Brien in the book Melly Aida and M. Farid Al Rianto, entitled Regional Cooperation in Management and Protection of the Marine Environment in the Malacca Strait, a country has internal sovereignty and external sovereignty. Internal sovereignty means that the state has legislative, executive and judicial jurisdiction over every activity in its territory. Recognition of sovereignty over natural resources was first stated in UN General Assembly Resolution No. 1803 of 1962 concerning Permanent Sovereignty over Natural Resources. Principle 21 
The Stockholm Declaration states that countries, based on the UN Charter and international legal principles, are sovereign to exploit their natural resources and are responsible for ensuring that activities in their jurisdiction or control do not cause environmental damage to other countries or to areas outside the national jurisdiction of a country (Mangku\&Itasari;2015). Principle 21 was adopted by the ICJ in the Advisory Opinion in the case of the Legality of the Use of Nuclear Weapons in 1996. Based on this principle, the state has sovereignty over its territory and carry out activities in its territorial territory. However, the exercise of sovereignty must not violate international law. The principle of state sovereignty over its natural resources cannot be separated from the obligation of the state to guarantee not to damage the environment of other countries and the environment in their own jurisdiction.

a. Principle of Preventive Action In addition to being mentioned in the 21st Principle of the Stockholm Declaration, the principle of preventive action is also mentioned in the 2nd Principle of the United Nations Conference on Environment and Development (UNCED). This principle has two perspectives. First, this principle requires to minimize environmental damage as the main objective. Second, the state is obliged to prevent environmental damage in and through its jurisdiction, including regulatory, administrative and other actions. Even in the United States of Foreign Affairs Law, it is stated that the state's obligation is not only to take preventative measures, but also to reduce and control any environmental losses that occur. In the case of crossborder pollution, each country is required to carry out two obligations, first, to take the necessary actions in good faith; second to regulate public and private activities which are the subject of its jurisdiction (Aida, et. al, 2015: 38).

b. Co-operation

The principle of this cooperation originates from the general principle of good neighborliness which can be found in customary international law as well as in Article 74 of the UN Charter. This principle is reflected in several international treaties and is supported by the country's main practices in dangerous and emergency activities (Purwanto\&Mangku;2016). Cooperation is contained in the 24th Principle of the Stockholm Declaration and the 27th Principle of the Rio Declaration which states that countries must cooperate in the principles of good faith and the spirit of partnership as efforts to protect the environment.

c. Sustainable Development

The principle of sustainable development emphasizes that current development must not reduce the rights of future generations. In other words, the development carried out must pay attention to the ability of the environment in meeting the needs of future generations. The principle of 
sustainable has several aspects, namely (Isfarin, 2012: 213):

1) The need to take into consideration the needs of present and future generation

2) The acceptance on environmenat protection grounds, of limit placed upon the use and exploitation of natural resources

3) The role of equitable principles in the allocation of rights and obligation

4) The need to integrate all aspects of environment and the development

5) The need to interpret and apply rules of international law in an integrated and systemic manner.

\section{d. Precutionary Principle}

This principle states that the absence of conclusive and conclusive scientific findings or evidence cannot be used as a reason to delay efforts to prevent environmental damage. As stated in Principle 15 of the Rio Declaration "where there are threats of serious or irreversible damage, lack of full scientific certainly shall not be used as a reason for postponing costeffective measures to prevent environmental degradation".

e. Polluter Pays Principle

The Organization for Economic Cooperation and Development (OECD) formulates polluter pays principle in environmental Principles and Concepts as (OECD, 1992): "The principle to be used for allocating costs of pollution prevention and control measures to encourage rational use of scarce environmental resources and to avoid distortions in international trade and investment is so called polluter pays principle. That principle means that polluter should bear the expenses of caring out above mentioned measures decided by the public authorities to ensure that the environment is in an acceptable states. In the other world the costs of these measures should be reflected in the costs of goods and services which causes pollution in production and / or consumption (Purwendah, Mangku \& Periani ;2019). Such measures should not be accompanied by subsidies that would create significant distortions in international trade and investment " economy, protection of society and the environment. This principle is also intended to allocate costs for environmental restoration activities so that it is not borne by people who do not benefit directly from an economic activity and there is a reduction in the burden of the state in financing environmental pollution as a result of economic activity.

In its development polluter pays principle is not only understood as an economic instrument but also the meaning in terms of legal liability (Muhdar, 2010: 7-8). Accountability in international environmental pollution is not only related to which country is responsible, but furthermore which legal subjects (both individuals and legal entities) can be held accountable and claimed for compensation for environmental damage (Anom, 2009: 99). 
f. Principle of Common But Differentiated Responsibility

This principle was developed from the principle of equality in international law and the recognition of special treatment for developing countries. In Article 7 of the Rio Declaration it is stated that countries have the same obligation to cooperate in conserving, protecting and restoring the earth's ecosystems while taking into account different contributions to developed and developing countries. Protection of the marine environment within the framework of international law is actually an accumulation of The Principle of National Sovereignity and The Freedom of High Sea. The International Maritime Organization (IMO) states that "a right on the part of an astat threatened with the environmental injury from sources beyond its territorial jurisdiction, at least where those sources are located on the high seas, to take reasonable action to prevent or abate that injury "(IMO, 1988: 2). In the context of national law, Law Number 32 of 2009 concerning Environmental Protection and Management provides an understanding of the environment as a unitary space with all objects, forces, and living things, including humans and their behavior, which affect nature itself, survival, and the welfare of humans and other living things. In Law No. 32 of 2009 Article 1 number 16, environmental damage is the actions of people who cause direct or indirect changes in the physical, chemical and / or biological nature of the environment so that it exceeds the standard criteria for environmental damage. Whereas the standard criterion for environmental damage is a measure of the limits of changes in the physical, chemical and / or biological nature of the environment which can be tolerated by the environment in order to be able to preserve its functions. The principle of protection and management contained in the Act. No. 32 of 2009 carried out based on the principle of:

a. State responsibility;

b. Sustainability and sustainability;

c. Harmony and balance;

d. Cohesiveness;

e. The benefits;

f. Caution;

g. Justice;

h. Ecoregion;

i. Biodiversity;

j. Polluters pay;

k. Participatory;

1. Local culture;

$\mathrm{m}$. Good governance; and

n. Regional autonomy.

In the explanation of Law No. 32 of 2009 concerning Environmental Protection and Management states that the principle of state responsibility intends and aims at ensuring that the utilization of natural resources will provide maximum benefits for the welfare and quality of life of the people, both current and future generations. The state guarantees the rights of its citizens to a good and healthy environment, and the state prevents the use of natural resources that cause pollution and / or 
environmental damage. Whereas the principle of polluter pays is that any person responsible for a business and / or activity that causes pollution and / or environmental damage must bear the cost of environmental recovery.

\section{Protection and Preservation of the Marine Environment in UNCLOS}

On December 11, 1982 UNCLOS 1982, established the basic principles for marine structuring. In detail UNCLOS 1982 establishes the rights and obligations, sovereignty, sovereign rights and jurisdiction of countries in the use and management of the sea.

UNCLOS 1982 is divided into seventeen Chapters, and fourteen of them regulate various matters, namely among others about the meaning or term and scope of its application. Subsequent chapters contain provisions regarding territorial seas and additional zones; strait used for international shipping; archipelago state; exclusive economic zone; continental shelf; high seas; island; sea closed and half closed; the state's right of land to access to and from the sea and freedom of transit; deep sea area sub-regions (Regions); protection and preservation of the marine environment; marine scientific research; and development and transfer of marine technology. The last three chapters contain provisions regarding Dispute Resolution (Chapter XV), General Provisions (Chapter XVI) and Closing Provisions. Protection and preservation of the marine environment is contained in Chapter XII of UNCLOS, where there are 11 parts of paragraph 193237. Article 192 states that, which asserts that each State has an obligation to protect and preserve the marine environment. Article 193 outlines an important principle in the utilization of resources in the marine environment, namely the principle that reads: that each State has the sovereign right to exploit its natural resources in accordance with their environmental policies and in accordance with their obligations to protect and preserve the marine environment.

The 1982 Law of the Sea Law requires each State to make efforts to prevent, reduce, and control pollution of the marine environment from every source of pollution, such as pollution from the disposal of hazardous and toxic waste originating from land sources ( land-based sources), dumping, from ships, from exploration and exploitation installations. In various efforts to prevent, reduce and control environmental pollution, each State must cooperate both regionally and globally as stipulated by Article 197201 of the 1982 Law of the Sea Law.

In carrying out its obligations to protect and preserve the marine environment, each country is required to cooperate both regionally and globally. The obligation to carry out regional and global cooperation (global and regional co-operation) is regulated by Article 197-201 of the Law of the Sea Convention 1982. Article 197 of the Convention reads: 
"Countries must cooperate globally and regionally directly or through international organizations in formulate and explain international provisions and standards as well as suggested procedures and practices in accordance with the Convention for the protection and preservation of the marine environment with due regard to regional conditions " (Nur, 2016: 3).

Regional and global cooperation can be in the form of cooperation in the notification of sea pollution, joint prevention of hazards for occurrence of sea pollution, the formation of contingency plans against pollution, studies, research, information and data exchanges and making scientific criteria (scientific criteria) to regulate procedures and practices for the prevention, reduction and control of pollution of the marine environment as affirmed by Article 198-201 of the 1982 Law of the Sea Law. In addition, Article 207-212 of the 1982 Law of the Sea Law requires each State to make laws and regulations that govern prevention and control of marine pollution from various sources of pollution, such as land-based sources, pollution from seabed activities in their national jurisdiction (pollution from sea-bed activities to national jurisdiction), pollution from activities in the Area (pollution from activities in the Area), pen pollution from dumping (pollution by dumping), pollution from ships (pollution from vessels), and pollution from air (pollution from or through the atmosphere).
UNCLOS 1982 regulates the protection of the marine environment and the preservation of the marine environment in Chapter XII which consists of Articles 192 - Article 237. Article 193 there are general provisions that States have sovereign rights to exploit natural resources in harmony with environmental policies and in accordance with the obligations of each country to protect and preserve the marine environment.

CHAPTER XII Article 197 regulates prevention measures to prevent, reduce and control pollution of the marine environment, including global and regional cooperation in formulating and explaining the provisions, standards and suggested practices and procedures for the protection and pedagat of global estarians the marine environment by taking into account regional characteristics that are typical.

a. In particular the protection of the marine environment from oil pollution has been regulated in IMO (International Maritime Organization) conventions. These conventions include: International Convention for the Prevention of Pollution of the Sea by Oil (OILPOL) 1954 This convention changed several times, until the last revised in 1971. This convention regulates the supervision of oily water waste discharges from ordinary ships and oil tanker, water ballast, oil making terminal and oil cargo record. 
b. International Convention Relating to Intervention on the High Seas in the case of Oil Pollution Casualties 1969 This convention authorizes states parties to take action against other countries' vessels involved in accidents or damage on the high seas if they are thought to result in pollution.

c. Convention on the Prevention of Marine Pollution by Dumping of Wastes and Other Matter (LDC) 1972 This agreement is global, prohibits the dumping of certain hazardous materials and requires special permits for certain wastes.

d. International Convention for the Prevention of Pollution from Ship 1973 (MARPOL) This convention was renewed in 1997, containing the technical provisions of pollution from ships (except dumping), applicable to all types of ships.

e. International Convention on Oil Pollution Preparedness, Response and Co-operation (OPRC) 1990 This convention aims to set the framework for global cooperation in dealing with accidents or threats of pollution to the marine environment. In addition to regulating the aspects of prevention, reduction and technical handling of pollution, IMO also makes conventions regarding liability and oil pollution compensation schemes. f. Convention on the Civil Liability for Oil Pollution Damage (CLC) 1969, updated 1976 and 1992.

g. Contaminants (boat owners) are subject to strict liability and compulsory liability insurance by this convention.

The 1971 Convention on the Establishment of an International Fund for Compensation for Oil Pollution Damage (FUND) was updated 1976, 1992, 2003. This convention establishes compensation arrangements for victims if compensation under the CLC is inadequate.

In addition to the Law of the Sea Convention, there are also other conventions that discuss the protection of the marine environment from pollution including, the International Convention on Civil Liability for Oil Pollution at Sea (International Convention on Civil Liability for Oil Pollution Damage). CLC 1969 is a convention governing compensation for oil pollution due to oil tanker accidents. This convention applies to pollution of the marine environment in the territorial sea of the participating State. In the case of responsibility for compensation for pollution of the marine environment, the principle used is the principle of absolute responsibility.

London Dumping Convention is an International Convention to prevent dumping, which means the disposal of hazardous waste whether from ships, aircraft or industrial plants. The convention States are obliged to pay attention to the 
dumping action. Dumping can cause sea pollution which results in health threats to humans, damaging ecosystems and disrupting the comfort of passages at sea.

OPRC or The International Covention on Oil Pollution Preparedness Response and Cooperation 1990 is a convention of international cooperation tackling marine pollution due to oil spills and dangerous toxic materials. From the existing understanding, we can conclude that this Convention quickly provides assistance or assistance to victims of marine pollution, this assistance by providing assistance equipment so that victims' recovery and evacuation efforts can be addressed immediately.

Marpol 73/78 is an international convention for the prevention of pollution from ships, 1973 as amended by the 1978 protocol. Marpol 73/78 is designed with the aim of minimizing marine pollution, and preserving the marine environment through the complete elimination of pollution by oil and other dangerous substances and minimizing the disposal of substances -The delicious is accidental.

\section{Conclution}

Perlindungan dan pelestarian terhadap laut merupakan hal yang sangat penting dilakukan, karena mengingat segala kebutuhan mahkluk hidup disokong oleh lingkungan laut baik dari segi ekonomu, primer, maupun sekunder. Banyak manfaat yang dihasilkan dilingkungan laut, maka kemungkinan pencemaran terhada lingkungan laut bias saja terjadi yang dilakukan oleh oknumoknum yang tidak bertanggungjawab. Dalam perspektif hukum internasional pencemaran lingkungan diatur di dalam UNCLOS 1982 tepatnya pada Bab XII. Sesuai dengan pasal 192 serta 193 menyatakan bahwa setiap negara mempunyai kewajiban untuk melindungi serta melestarikan lingkungan laut. Dalam perlindungan dan pelestarian laut, ada beberapa prinsip umum yaitu: Sovereignity Over Natural Resources and the Responbility not to Cause Damage to the Environment of other States or to Areas Beyond National Jurisdiction; Principle of Preventive Action; Co-operation; Sustainable Development ; Precutionary Principle; Polluter Pays Principle; Principle of Common But Differentiated Responsibility.

\section{References}

Aida, Melly, et. al. 2015. Kerja Sama Regional Dalam Pengelolaan dan Perlindungan Lingkungan Laut di Selat Malaka. Edisi Revisi Seri Monograf Volume 3 Tahun 2015. Lampung: BP. Justice Publisher.

Anom, Surya. 2009. Perlindungan Negara Terhadap Pencemaran Minyak di Pelabuhan Akibat Operasi Kapal Tanker Berdasarkan UNCLOS 1982. Thesis. Fakultas Hukum, Universitas Gadjah Mada.

Candra. 2015. “Kasus Baru Tumpahan Minyak Di Perbatasan 
Indonesia - Singapura Januari 2015". Tersedia pada http:// pusriskel.litbang.kkp. go.id/index.php/e n/home/553-kasus-barutumpahan-minyak-diperbatasanindonesiasingapura-2-januari2015 (diakses tanggal 28 April 2018).

Masdin. (2016). “Implementasi Ketentuan-Ketentuan United Nations Convention on The Law of The Sea (UNCLOS) 1982 Terhadap Perlindungan dan Pelestarian Lingkungan Laut di Indonesia". Jurnal Ilmu Hukum Legal Opinion, Edisi 2, Volume 4.

Parthiana, I Wayan. 2002. Hukum Perjanjian Internasional Bagian 1. Bandung: CV. Mandar Maju.

Rusmana, Muliadi. 2012. "Perlindungan Terhadap Pencemaran Lingkungan Laut Di Kawasan Asia Tenggara Dalam Perspektif Hukum Lingkungan Internasional". Tersedia pada http:/ / muliadirusmana.blogs Mangku, D. G. S. (2010). Pelanggaran terhadap Hak Kekebalan Diplomatik (Studi Kasus Penyadapan Kedutaan Besar Republik Indonesia (KBRI) di Yangon Myanmar berdasarkan Konvensi Wina 1961). Perspektif, 15(3).

Mangku, D. G. S. (2011). Peluang dan tantangan ASEAN dalam penyelesaian sengketa Kuil pot.com/2012/12/pencemara n-lingkungan-laut.html (diakses tanggal 11 Maret 2018).

Isfarin, Nadia Nurani. (2012). "Perlindungan Lingkungan Laut Selat Malaka Dari Pencemaran Minyak Lintas Batas". Jurnal Ilmu Hukum, Vol. 15 No. 2 (hlm. 206-224).

Syofyan, Ahmad. "Tanggung Jawab dalam Pencemaran Laut yang disebabkan minyak menurut Hukum Internasional". Fiat Justitia, Jurnal Ilmu hukum Vol. 6 Nomor 1 Januari-April. International Convention on Civil Liability for Oil Damage. 1969. Done at Brussels on 29 November 1969. Entered into force on 19 June 1975. Submitted and Registered on International Maritime Organization on 27 June 1975.

Nur, Indah Azizah. (2016). "Perlindungan dan Pelestarian Lingkungan Laut Dalam Hukum Laut Internasional" Jurnal Hubungan Internasioal, Vol. 04 Nomor 2.

Preah Vihear di perbatasan Kamboja dan Thailand. Pandecta: Research Law Journal, 6(2).

Mangku, D. G. S. (2012). Suatu Kajian Umum tentang Penyelesaian Sengketa Internasional Termasuk di Dalam Tubuh ASEAN. Perspektif, 17(3).

Mangku, D. G. S. (2013). Kasus Pelanggaran Ham Etnis 
Rohingya: Dalam Perspektif

ASEAN. Media Komunikasi

FIS, 12(2).

Mangku, D. G. S., \& Itasari, E. R. (2015). Travel Warning in International Law Perspective. International Journal of Business, Economics and Law, 6(4).

Purwanto, H., \& Mangku, D. G. (2016). Legal Instrument of the Republic of Indonesia on Border Management Using the Perspective of Archipelagic State. International Journal of Business, Economics and Law, 11(4).

Purwendah, E., Mangku, D., \& Periani, A. (2019, May). Dispute Settlements of Oil Spills in the Sea Towards Sea Environment Pollution. In First International Conference on Progressive Civil Society (ICONPROCS 2019). Atlantis Press. 